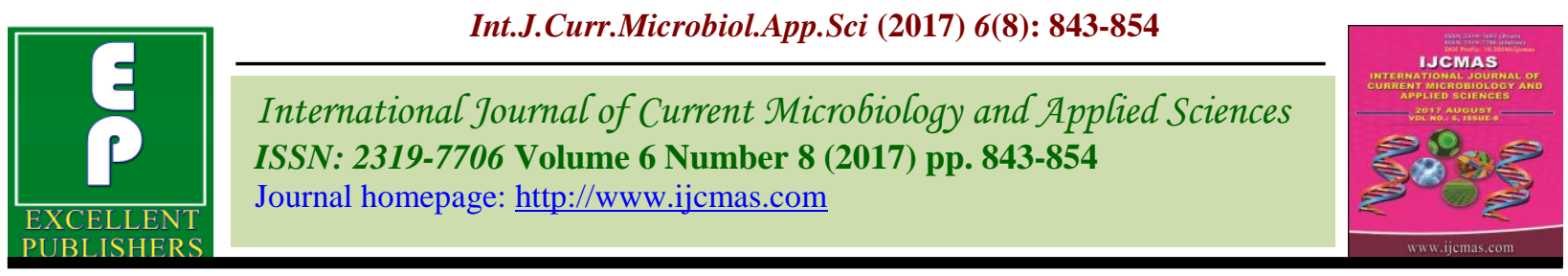

Original Research Article

https://doi.org/10.20546/ijcmas.2017.608.107

\title{
Effect of Biological Seed Coating on Pigeonpea Seedling Vigour
}

\author{
V. Jagadeesh ${ }^{1}$, Sujatha Patta ${ }^{1}$, S. Triveni ${ }^{2}$, K. Keshavulu ${ }^{1}$, \\ K. Jhansi Rani ${ }^{1}$ and Kavali Raghavendra ${ }^{3}$ \\ ${ }^{1}$ Department of Seed Science and Technology, PJTSAU, Rajendranagar, Hyderabad 30, India \\ ${ }^{2}$ Department of Agriculture Microbiology and Bio-energy, PJTSAU, Rajendranagar, Hyderabad \\ ${ }^{3}$ Centor India, Hyderabad, Telangana, India \\ *Corresponding author
}

\section{A B S T R A C T}

Keywords

Pigeonpea,

Seedling vigour,

Biocoating,

Biocontrol,

Polymers,

Biofertilizers.

Article Info

Accepted:

14 June 2017

Available Online:

10 August 2017
The present investigation was carried out to study the effect of biological seed coating with bioprotectants and biofertilizers using polymer on the seed quality and storability of pigeonpea. The pigeonpea seed was coated with Trichoderma viride and Pseudomonas fluorescens with combinations of Rhizobium or Phosphorus Solubilizing Bacteria using two adjuvants like polymer and sugar syrup. The seedling vigour parameters were studied at monthly intervals during storage period of six months. Six months after treatment, seed combinely inoculated with Trichoderma and Rhizobium (1314 and 69, respectively for SVI1 and as SVI 2 and Pseudomonas and Phosphorus Solubilizing Bacteria 1178 and 69, respectively for SVI1 and as SVI 2 showed high seedling vigour. Among adjuvants, biopolymer recorded good vigour compared to farmer practice of sugar syrup. Seed combinely coated with bioprotectants and biofertilizers recorded more vigour compared to single organism inoculation. The results of the study thus indicated the possibility of coating seed with biological agents with effective biofriendly polymer as an adjuvant immediately after processing before packaging without affecting the seed quality. Thus, the farmers can be supplied biologically coated seed in advance and the general practice of treating the seed one day prior to sowing can be avoided.

\section{Introduction}

Pigeon pea [Cajanus cajan (L.)] is an important staple food pulse crop rich in protein content of $22 \%$, which is almost three times that of cereals. In India, pigeonpea is cultivated in an area of 3.90 mha with a production of $3.17 \mathrm{Mt}$ and productivity of 813 $\mathrm{kg} \mathrm{ha}^{-1}$ (IIPR, 2014 and FAO, 2016). The main constraints in obtaining potential yield of the pigeon pea are incidence of diseases, insects and other physiological stresses in the field. It is known to be affected by more than hundred pathogens, among them, pigeonpea wilt caused by Fusarium udum is the major disease in India. The disease may appear during early stages of plant growth (4-6 week old plant) period and essentially affects yield. This disease drastically influences the crop yield by poor field emergence, seedling establishment and plant stand in the field finally leading to the reduction in the productivity and production.

Moreover, the seed performance can be enhanced by the way of application of fungicides, insecticides and other protecting agents on to the seed surface by means of 
coating to protect the seed from pathogens. Biological seed coating is a new technique of seed treatment through which biological agent will be coated over seed surface by mixing in a polymer that is sprayed on the seeds as they fall through a specialized machine. The polymer is rapidly dried, so that the seeds emerge with a complete, dry polymeric coating containing biological control agent. By encasing the biological control agent within a thin film of biodegradable polymer, the adherence of seed treatment to the seed is improved, ensures dust free handling, making treated seed both useful and ecofriendly. It is recently used as an alternative method for controlling many seed and soil-borne pathogens. It is an ecological approach using selected fungal antagonists against the soil and seed-borne pathogens and it has a potential to provide an alternative to chemical control. Considering the importance of the biological agents in the eco-friendly control of pests and diseases, it is very important to treat the seed before taking up of sowing. Even though seed treatment with biological agents is not new, the main constraint is that the seed treatment can only do just before the sowing.

In India, there are meager or no studies to encourage seed treatment with biological agents considerably after seed processing. In this connection, the adjuvants play a key role to improve the shelf life of bio agents and seed storability. Addition of certain polymers offers a ray of hope in this direction. The present study is planned to carry out biological seed treatment with polymer as an adjuvant well in advance of sowing i.e., immediately after seed processing or before packaging and to study the viability and shelf life of biological agent and its effect on seed storability. In this context, this research study is planned with the objective to study the effect of bio friendly polymer as an adjuvant on the viability and shelf life parameters of
Pseudomonas fluorescens, Rhizobium and Phosphorus solubilising bacteria and its effect on seed quality and storability of pigeon pea.

\section{Materials and Methods}

The present investigation was out during Kharif, 2015 and Rabi, 2016 at Department of Seed Science and Technology and Department of Agricultural Microbiology and Bio-energy, College of Agriculture, PJTSAU, Rajendranagar, Hyderabad, Telangana.

\section{Materials}

Freshly harvested seeds of Pigeonpea variety LRG - 41 were collected from Regional Agricultural Research Station, Lam, Guntur, Andhra Pradesh. The seed possessed initial germination of $85 \%$, electrical conductivity of seed leachates as $12.12 \mu \mathrm{mhos} / \mathrm{cm}$ and seed moisture content of $8.1 \%$. Biological agents like Trichoderma viride, Pseudomonas fluorescens, Rhizobium spp and Phosphorous Solubilizing Bacteria were obtained from Agri Biotech Foundation (ABF), Rajendranagar, Hyderabad and Telangana. Bio friendly polymer was collected from Centor India, Bliss Paradise; Hitex, Secunderabad, Telangana.

\section{Methodology}

For biological seed coating, two different adjuvants like bio friendly polymer or sugar syrup were used @ $6 \mathrm{~g} \mathrm{~kg}^{-1}$ seed. Biological agents like Pseudomonas fluorescens, Rhizobium and Phosphorous Solubilizing Bacteria were used @ $12 \mathrm{~g} \mathrm{~kg}^{-1}$ seed. These biological agents were used for coating either individually or in combination of two. For each treatment, $600 \mathrm{~g}$ pigeon pea seed was weighed separately and placed into seed coating machine. Biological coating material was prepared by weighing $6 \mathrm{~g}$ of adjuvant (either bio friendly polymer or sugar syrup) 
into a beaker and to that $3.6 \mathrm{~g}$ of distilled water was added and mixed thoroughly. To this diluted adjuvant, $12 \mathrm{~g}$ of biological agent was added and mixed thoroughly. For combined inoculation of two biological agents $6 \mathrm{~g}$ of each organism was used for preparing slurry. Uniformly coated seed was removed from the coating machine and was shade dried for $2 \mathrm{hr}$. This treated seed was then made into 3 replications@200 g each and packed in zip lock polythene covers and kept for storage under ambient conditions.

Pigeonpea biological seed coating with Trichoderma viride, Rhizobium and phosphorus solubilizing bacteria using polymer

T1: Seed + Trichoderma viride + polymer T2: Seed + Trichoderma viride + Sugar syrup T3: Seed + Trichoderma viride + Rhizobium + polymer

T4: Seed + Trichoderma viride + Rhizobium + Sugar syrup

T5: Seed + Trichoderma viride + Phosphorus Solubilizing Bacteria (PSB) + polymer

T6: Seed + Trichoderma viride + Phosphorus Solubilizing Bacteria (PSB) + Sugar syrup T7*: Seed + Trichoderma viride + polymer T8: Seed + Thiram T9: Seed (Untreated Control)

*Note: Farmer practice of seed inoculation as one day before sowing (fresh treatment every month).

Pigeonpea biological seed coating with Pseudomonas fluorescens, Rhizobium and phosphorus solubilizing bacteria using polymer

T1: Seed + Pseudomonas fluorescens+ polymer

T2: Seed + Pseudomonas fluorescens + Sugar syrup

T3: Seed + Pseudomonas fluorescens+ Rhizobium + polymer
T4: Seed + Pseudomonas fluorescens+ Rhizobium + Sugar syrup

T5: Seed + Pseudomonas fluorescens+ Phosphorus Solubilizing Bacteria (PSB) + polymer

T6: Seed + Pseudomonas fluorescens+ Phosphorus Solubilizing Bacteria (PSB) + Sugar syrup

T7*: Seed + Pseudomonas fluorescens + polymer

T8: Seed + Thiram

T9: Seed (Untreated Control)

*Note: Farmer practice of seed inoculation as one day before sowing (fresh treatment every month).

Testing of seed quality and storability of biologically coated pigeonpea seed

\section{Seed germination (Percent)}

The laboratory test for germination was conducted as per the ISTA rules (ISTA, 2009) by adopting between paper method. Three replications of 100 seeds each were taken from each treatment and uniformly place on germination paper. The rolled towel was kept in the seed germinator and maintained a constant temperature of $25 \pm 0.5^{\circ} \mathrm{c}$ and 95 per cent relative humidity. Evaluation of normal seedlings, abnormal seedlings, fresh ungerminated seeds and dead seeds were done on sixth day. Germination percentage is expressed on the number of normal seedlings by following

Germination $\%=$

Number of normal seedlings

Total number of seeds planted

\section{Seedling length $(\mathrm{cm})$}

Ten normal seedlings were selected randomly per replication in each treatment on $6^{\text {th }}$ day of germination test. The root length was 
measured from the tip of the primary root to base of the hypocotyl with the help of a scale and the mean root length was expressed in centimeters.

Ten normal seedlings used for root length measurement, were also used for the measurement of shoot length. The shoot length was measured from the tip of the primary leaf to the base of the hypocotyl and mean shoot length was expressed in centimeters.

\section{Seedling dry weight (g)}

Ten seedlings in each replication of germination test were oven dried in hot air oven at $80^{\circ} \pm 1^{\circ} \mathrm{C}$ for one day and dry weight per seedling was expressed in grams (g).

\section{Seedling vigour index I}

Seedling vigour index was calculated using the formula given by Abdul Baki and Anderson (1973) and expressed in whole number.

Seedling vigour index $=$ Germination percentage $(\%) \times$ Seedling length $(\mathrm{cm})$

\section{Seedling vigour index II}

Seedling vigour index II was calculated as per the method suggested by Abdul-Baki and Anderson (1973) and expressed in whole number.

Seedling vigour index II = Germination percentage $(\%) \times$ Seedling dry weight $(\mathrm{g})$

\section{Electrical conductivity $\left(\mu \mathrm{mhos} 50 \mathrm{seed}^{-1}\right)$}

Fifty seeds, in two replicates, were subjected to 3-4 washings in distilled water, with various shaking. The seeds were then soaked in $50 \mathrm{ml}$ of distilled water at $25 \pm 1^{0} \mathrm{C}$ temperature, for $24 \mathrm{hrs}$, with frequent stirring. The leachate was decanted and conductance was estimated by using a conductivity meter. The reading obtained was multiplied with cell constant, after deducting the conductance of distilled water, and the data was expressed in $\mathrm{dSm}^{-1}$.

\section{Statistical analysis}

The data recorded were analyzed statistically by adopting Completely Randomized Design (CRD), as described by Panse and Sukhatma (1985) and the standard error of difference was calculated at $5 \%$ probability level to compare the mean difference among the treatments. The data recorded as percentage were transformed to the respective angular (arc sin) values before subjecting them to statistical analysis.

\section{Results and Discussion}

\section{Effect of biological seed coating with bioprotectants and biofertilizers on pigeonpea seedling vigour index-1}

The data on the effect of biological seed coating with Trichoderma and bio fertilizers using polymer on seedling vigour index 1 was computed based on seedling length and seed germination percentage and were presented in table 1 . The mean seedling vigour index 1 recorded at initial and 6 month of storage period was 2042 and 977, respectively. At the end of six months of storage, there was about $52 \%$ reduction in the mean SVI-I. The highest seedling vigour index 1 (1314) was recorded in seeds treated with Trichoderma, Rhizobium using polymer (T3) and it is significantly differed from all other treatments. The lowest seedling vigour index 1(640) recorded in seeds treated with Trichoderma with sugar syrup. Similar trend was also observed with regard to biological 
seed coating with Pseudomonas (Table 1). The highest seedling vigour index 1 (1178) was recorded in the seeds treated with Pseudomonas, PSB using polymer (T5) and lowest (806) was recorded in the seeds treated with Pseudomonas and PSB with sugar syrup.

The effect of adjuvants on the seedling vigour index 1 of biologically coated seed pigeonpea was presented in figures 1 and 2. Polymer as an adjuvant showed slightly higher vigour (1077 with Trichoderma and 1040 with Pseudomonas) but sugar syrup reported lower vigour (814).

The effect of type of inoculation on seedling vigour index 1 of biologically coated pigeonpea seed was presented in figures 3 and 4. Combined inoculation of Trichoderma viride (1143) or Pseudomonas (1111) with Rhizobium or PSB and showed higher vigour compared to single inoculation of Trichoderma (1010) or Pseudomonas (969).

\section{Effect of biological seed coating with} bioprotectants and biofertilizers on pigeonpea seedling vigour index-2

A gradual decrease in the seedling vigour index II was also observed with the advancement of storage period (Table 2 ). The mean seedling vigour index -2 recorded at initial and 6 month of storage period was 88 and 62 , respectively. At the end of six months of storage, there was $30 \%$ reduction in the mean SVI 2. Highest seedling vigour index- 2 (69) was recorded in seeds treated with Trichoderma and Rhizobium using polymer (T3) and it was significantly differed from that of control. The lowest vigour index-2 (54) was recorded in seeds treated with Trichoderma using sugar syrup (T2). Except for sugar syrup (T2, T4 and T6), all other treatments were found to be at par with each other with regard to good SVI II and seed storability at 6 months storage. Similar trend with regard to SVI 2 was also observed with
Pseudomonas treatments. Six months after storage, seed treated with Pseudomonas and Phosphorus Solubilizing Bacteria (PSB) using polymer (T5) was found superior for seedling vigour index-2 (69) and it was differed significantly from that of all other treatments.

The effect of adjuvants on the seedling vigour index-2 of biologically coated seed pigeonpea was presented in figures 5 and 6 . Polymer showed slightly on par vigour index-2 (64) compared to seed coated with fungicide and untreated control (65) and sugar syrup reported lower vigour index-2 (56).

These findings are in conformity with the findings of Verma and Verma (2014) in soybean, Kaushik et al., (2014) in maize, Ambika et al., (2014) in hybrid rice and Shakuntala et al., (2014) in sunflower who have reported good Vigour index-2 in polymer coated seed. In a similar study Vinod et al (2013) reported that all the seed quality parameters viz., 100 seed weight, germination percentage, seedling length, seedling dry weight, vigor index and electrical conductivity were found to higher in seeds obtained from seeds treated with deltamethrin $2.8 \mathrm{EC}$ at $0.3 \mathrm{ml} / \mathrm{kg}$ seeds+vitavax power at 3 $\mathrm{g} / \mathrm{kg}$ seed+polymer seed coating at $5 \mathrm{ml} / \mathrm{kg}$ seeds.

The effect of type of inoculation on seedling vigour index-2 of biologically coated pigeonpea seed was presented in the figures 7 and 8. Combined inoculation showed higher seedling vigour index-2 (69) compared to single inoculation.

Effect of biological seed coating with Trichoderma viride, Rhizobium, PSB using polymer on electrical conductivity ( $\mu$ mhos 50 seed $^{-1}$ )

The data presented in table 3 showed a significant effect of biological seed coating of bioprotectants, biofertilizers with adjuvants 
on electrical conductivity ( $\mu$ mhos 50 seed $^{-1}$ ). Electrical conductivity was increased progressively with the advancement of storage period (18.69 to 37.61 with Trichoderma and 15.99 to 30.93 with Pseudomonas).

At the end of six months of storage period, lowest electrical conductivity was recorded with polymer (28.81 with Trichoderma viride and 22.62 with Pseudomonas) compared to untreated control (35.41). And highest electrical conductivity (43.06) was recorded in seed, treated with Trichoderma and PSB using sugar syrup. And highest electrical conductivity (35.43) was recorded in seed, treated with Pseudomonas and Rhizobium with sugar syrup. There was a significant difference among the treatments with regard to electrical conductivity.

The effect of adjuvants on the electrical conductivity was presented in the figures 9 and 10. Throughout the storage period, polymer as an adjuvant reported lower leachates compared to untreated control.

Six months after storage, sugar syrup reported higher electrical conductivity (41.81). These findings are in line with Chachalis and Smith (2001) who have reported that seed coating with hydrophobic polymer Vinamul 3650 could lower the solute leakage in aged soybean seeds compared to sugar syrup.

The effect of type of inoculation on electrical conductivity of biologically coated pigeonpea seed was presented in the figures 11 and 12 .

Seed coating with single biological organism, showed more electrical conductivity (32.96 with Trichoderma, and 33.03 with Pseudomonas) compared to combined inoculation of bioprotectant and biofertilizers.
Effect of biological seed coating with bioprotectants and biofertilizers on pigeonpea seedling vigour index-1 and 2

The highest seedling vigour index 1 was recorded in seeds treated with Trichoderma, Rhizobium using polymer and Pseudomonas, $P S B$ using polymer. The lowest seedling vigour index 1 recorded in seeds treated with sugar syrup. These results revealed that polymer coating improved the seed storability by maintaining seed vigour. These findings are in conformity with the findings of Yadav et al., (2010) in chick pea, Singh et al., (2013) in Trigonella foenumgraecum, Kaushik et al., (2014) in maize, Ambika et al., (2014) in hybrid rice, Shakuntala et al., (2014) in sunflower, who have reported an increase in seed germination and seedling vigour in the polymer coated seeds compared to uncoated seeds. Similarly, Kaushik and Kumar (2014) reported that the seed treatment with polymer @ $9 \mathrm{ml}+$ thiram $2 \mathrm{~g}$ per $\mathrm{kg}$ of seed observed significant shoot length, root length, seedling length, viability, fresh weight and higher vigor index and high germination rate was observed for seed coated with polymer @6 $\mathrm{ml}+$ thiram $2 \mathrm{~g}$ per $\mathrm{kg}$ of seed after 6 month of storage.

Among adjuvants, polymer recorded more seedling vigour indices compared to farmer practice of sugar syrup. This might be due to the fact that polymer might have reduced the rate of deterioration and might have supplied sufficient nutrients to the seedling.

Combined inoculation of bioprotectants and biofertilizers also recorded good seedling vigour than single inoculation. This might be due to the fact that bioprotectants might give protection during seed storage and biofertilizers might have supplied sufficient nutrients to the young seedling. 
Table.1 Effect of biological seed coating with bio-protectants and bio-fertilizers on seedling vigour index 1 and storability of pigeon pea

\begin{tabular}{|c|c|c|c|c|c|c|c|c|}
\hline \multirow{2}{*}{ Treatment } & \multicolumn{4}{|c|}{ Seed coating with Trichoderma viride, } & \multicolumn{3}{c|}{$\begin{array}{c}\text { Seed coating with Pseudomonas } \\
\text { fluorescens, Rhizobium and PSB }\end{array}$} \\
\cline { 2 - 9 } & $\mathbf{0 M A S}$ & $\mathbf{2 M A S}$ & $\mathbf{4 M A S}$ & $\mathbf{6 M A S}$ & $\mathbf{0 M A S}$ & $\mathbf{2 M A S}$ & 4MAS & $\mathbf{6 M A S}$ \\
\hline $\mathbf{T}_{\mathbf{1}}$ & 2104 & 1722 & 1373 & 1043 & 2032 & 1721 & 1240 & 1125 \\
\hline $\mathbf{T}_{\mathbf{2}}$ & 2092 & 2044 & 1477 & 898 & 2163 & 1982 & 1360 & 966 \\
\hline $\mathbf{T}_{\mathbf{3}}$ & 2113 & 1793 & 1315 & 1314 & 2010 & 1771 & 1215 & 1044 \\
\hline $\mathbf{T}_{\mathbf{4}}$ & 2049 & 1715 & 1328 & 640 & 2033 & 1563 & 1083 & 852 \\
\hline $\mathbf{T}_{\mathbf{5}}$ & 2094 & 1587 & 1306 & 972 & 2105 & 1860 & 1391 & 1178 \\
\hline $\mathbf{T}_{\mathbf{6}}$ & 2013 & 1725 & 1414 & 904 & 2097 & 1646 & 1340 & 806 \\
\hline $\mathbf{T}_{\mathbf{7}}$ & 2078 & 1817 & 1155 & 1051 & 2120 & 1679 & 1022 & 910 \\
\hline $\mathbf{T}_{\mathbf{8}}$ & 2283 & 1650 & 1227 & 999 & 2108 & 1690 & 1376 & 1110 \\
\hline $\mathbf{T}_{\mathbf{9}}$ & 2060 & 1690 & 1311 & 969 & 2007 & 1689 & 1339 & 1028 \\
\hline $\mathbf{M e a n}$ & $\mathbf{2 0 9 8}$ & $\mathbf{1 7 6 4}$ & $\mathbf{1 3 4 0}$ & $\mathbf{9 7 7}$ & $\mathbf{2 0 7 5}$ & $\mathbf{1 7 3 4}$ & $\mathbf{1 2 6 3}$ & $\mathbf{9 0 2}$ \\
\hline S.Em & 70.17 & 41.56 & 41.25 & 31.35 & 31.98 & 64.33 & 42.24 & 19.52 \\
\hline S.Ed & 99.24 & 58.77 & 58.34 & 44.34 & 45.22 & 90.97 & 59.73 & 27.61 \\
\hline CD $(\mathbf{0 . 0 5})$ & 210.12 & 124.43 & 123.53 & 93.87 & 95.75 & 192.62 & 126.47 & 58.47 \\
\hline C.V & 5.95 & 4.08 & 5.33 & 6.04 & 2.83 & 6.42 & 5.79 & 3.41 \\
\hline
\end{tabular}

Table. 2 Effect of biological seed coating with bio-protectants and bio-fertilizers on seedling vigour index 2 and storability of pigeon pea

\begin{tabular}{|c|c|c|c|c|c|c|c|c|}
\hline \multirow{2}{*}{ Treatment } & \multicolumn{3}{|c|}{$\begin{array}{c}\text { Seed coating with Trichoderma viride, } \\
\text { Rhizobium }\end{array}$} & \multicolumn{4}{c|}{$\begin{array}{c}\text { Seed coating with Pseudomonas } \\
\text { fluorescens, Rhizobium and PSB }\end{array}$} \\
\cline { 2 - 9 } & $\mathbf{0 M A S}$ & $\mathbf{2 M A S}$ & 4MAS & $\mathbf{6 M A S}$ & 0MAS & 2MAS & 4MAS & 6MAS \\
\hline $\mathbf{T}_{\mathbf{1}}$ & 88 & 78 & 71 & 65 & 79 & 76 & 75 & 64 \\
\hline $\mathbf{T}_{\mathbf{2}}$ & 82 & 77 & 70 & 54 & 81 & 78 & 73 & 60 \\
\hline $\mathbf{T}_{\mathbf{3}}$ & 85 & 78 & 71 & 68 & 77 & 75 & 70 & 64 \\
\hline $\mathbf{T}_{\mathbf{4}}$ & 82 & 82 & 71 & 57 & 77 & 73 & 66 & 56 \\
\hline $\mathbf{T}_{\mathbf{5}}$ & 88 & 80 & 73 & 63 & 79 & 78 & 73 & 69 \\
\hline $\mathbf{T}_{\mathbf{6}}$ & 85 & 79 & 71 & 58 & 77 & 75 & 70 & 56 \\
\hline $\mathbf{T}_{\mathbf{7}}$ & 84 & 78 & 68 & 65 & 80 & 74 & 68 & 65 \\
\hline $\mathbf{T}_{\mathbf{8}}$ & 81 & 76 & 68 & 65 & 80 & 77 & 75 & 65 \\
\hline $\mathbf{T}_{\mathbf{9}}$ & 87 & 79 & 72 & 66 & 77 & 76 & 72 & 65 \\
\hline $\mathbf{M e a n}_{\mathbf{S . E m}}$ & $\mathbf{8 8}$ & $\mathbf{7 9}$ & $\mathbf{7 1}$ & $\mathbf{6 2}$ & $\mathbf{8 0}$ & $\mathbf{7 6}$ & $\mathbf{7 1}$ & $\mathbf{6 3}$ \\
\hline S.Ed & 2.14 & 2.14 & 2.24 & 1.99 & 1.91 & 2.52 & 1.99 & 1.15 \\
\hline CD (0.05) & 3.03 & 3.03 & 3.17 & 2.81 & 2.71 & 3.56 & 2.82 & 1.63 \\
\hline C.V & N.S. & N.S. & N.S. & 5.96 & 5.74 & N.S. & 5.97 & 3.45 \\
\hline
\end{tabular}


Table.3 Effect of biological seed coating with bioprotectants and biofertilizers on Electrical conductivity ( $\mu$ mhos 50 seed-1) and storability of pigeon pea

\begin{tabular}{|c|c|c|c|c|c|c|c|c|}
\hline \multirow{2}{*}{ Treatment } & \multicolumn{4}{|c|}{$\begin{array}{c}\text { Seed coating with Trichoderma viride, } \\
\text { Rhizobium and PSB }\end{array}$} & \multicolumn{3}{c|}{$\begin{array}{c}\text { Seed coating with Pseudomonas } \\
\text { fluorescens, Rhizobium and PSB }\end{array}$} \\
\cline { 2 - 9 } & $\mathbf{0 M A S}$ & $\mathbf{2 M A S}$ & $\mathbf{4 M A S}$ & $\mathbf{6 M A S}$ & $\mathbf{0 M A S}$ & $\mathbf{2 M A S}$ & $\mathbf{4 M A S}$ & $\mathbf{6 M A S}$ \\
\hline $\mathbf{T}_{\mathbf{1}}$ & 19.18 & 34.18 & 36.40 & 37.12 & 17.28 & 24.80 & 29.10 & 33.03 \\
\hline $\mathbf{T}_{\mathbf{2}}$ & 19.21 & 33.48 & 41.07 & 42.94 & 20.51 & 28.84 & 35.10 & 36.90 \\
\hline $\mathbf{T}_{\mathbf{3}}$ & 17.29 & 22.44 & 31.14 & 42.07 & 17.91 & 24.08 & 30.57 & 32.80 \\
\hline $\mathbf{T}_{\mathbf{4}}$ & 19.61 & 36.55 & 41.04 & 41.22 & 16.14 & 16.48 & 33.80 & 35.43 \\
\hline $\mathbf{T}_{\mathbf{5}}$ & 19.12 & 29.24 & 37.47 & 38.60 & 13.66 & 16.88 & 21.70 & 22.62 \\
\hline $\mathbf{T}_{\mathbf{6}}$ & 17.10 & 21.58 & 42.17 & 43.06 & 11.81 & 20.84 & 33.70 & 33.91 \\
\hline $\mathbf{T}_{\mathbf{7}}$ & 16.48 & 26.30 & 28.81 & 29.10 & 17.62 & 30.94 & 31.40 & 33.71 \\
\hline $\mathbf{T}_{\mathbf{8}}$ & 14.30 & 23.21 & 31.25 & 31.34 & 13.65 & 20.64 & 29.80 & 33.76 \\
\hline $\mathbf{T}_{\mathbf{9}}$ & 13.53 & 20.41 & 34.54 & 35.41 & 12.30 & 20.74 & 25.50 & 26.70 \\
\hline $\mathbf{M e a n}_{\mathbf{S . E m}}$ & $\mathbf{1 7 . 3 1}$ & $\mathbf{2 6 . 9 9}$ & $\mathbf{3 7 . 6 1}$ & $\mathbf{3 8 . 1 4}$ & $\mathbf{1 5 . 9 9}$ & $\mathbf{2 3 . 4 2}$ & $\mathbf{3 0 . 5 0}$ & $\mathbf{3 0 . 9 3}$ \\
\hline S.Ed & 0.558 & 0.797 & 0.767 & 0.518 & 0.578 & 0.699 & 0.996 & 0.954 \\
\hline CD (0.05) & 0.789 & 1.128 & 1.085 & 0.732 & 0.818 & 0.989 & 1.408 & 1.349 \\
\hline C.V & NS & 2.387 & 2.298 & 1.550 & 1.732 & 2.093 & 2.981 & 2.855 \\
\hline
\end{tabular}

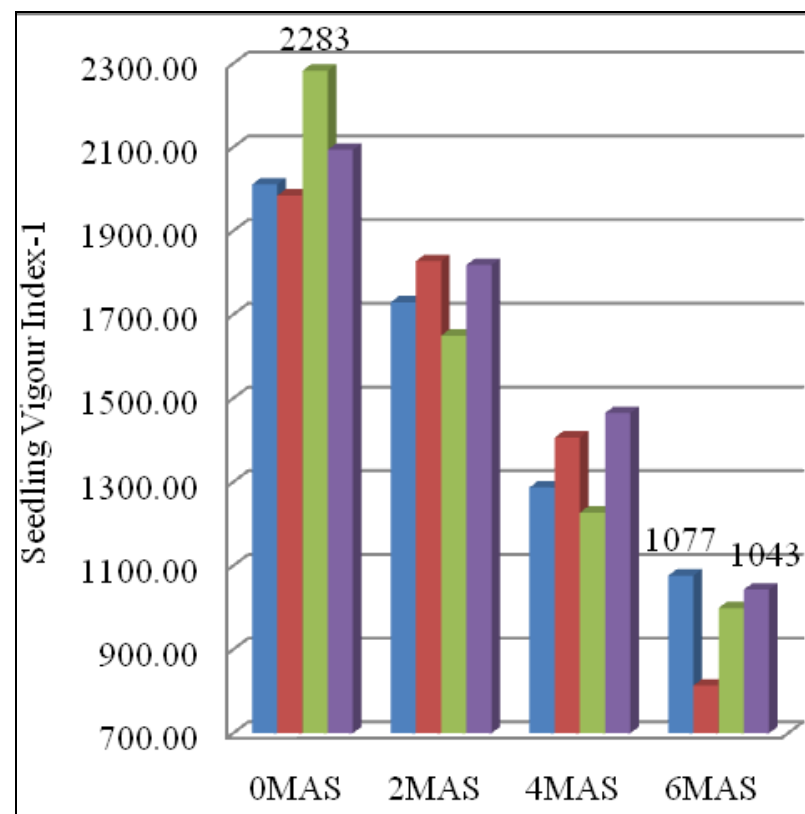

- Bio-polymer $\square$ Sugar syrup $\quad$ Fungicide $\approx$ Control Figure 1. Effect of seed coating material and Trichoderma, Rhizobium and PSB on SVI-1

Note: MAS-Months After Storage

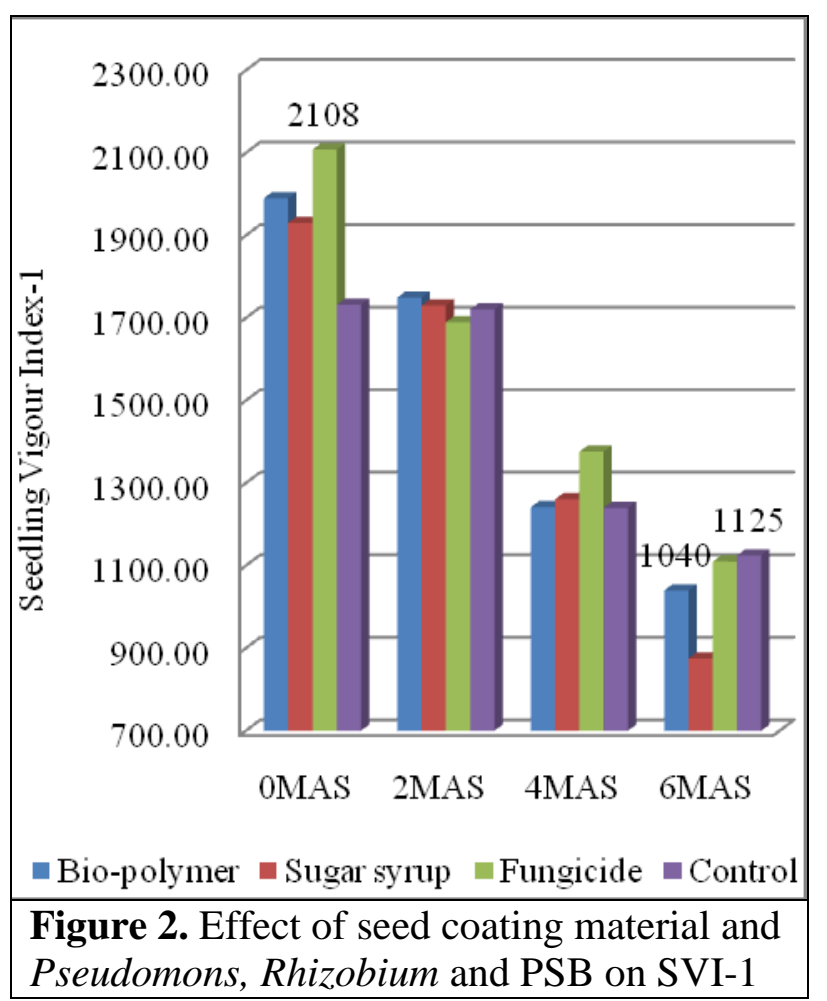




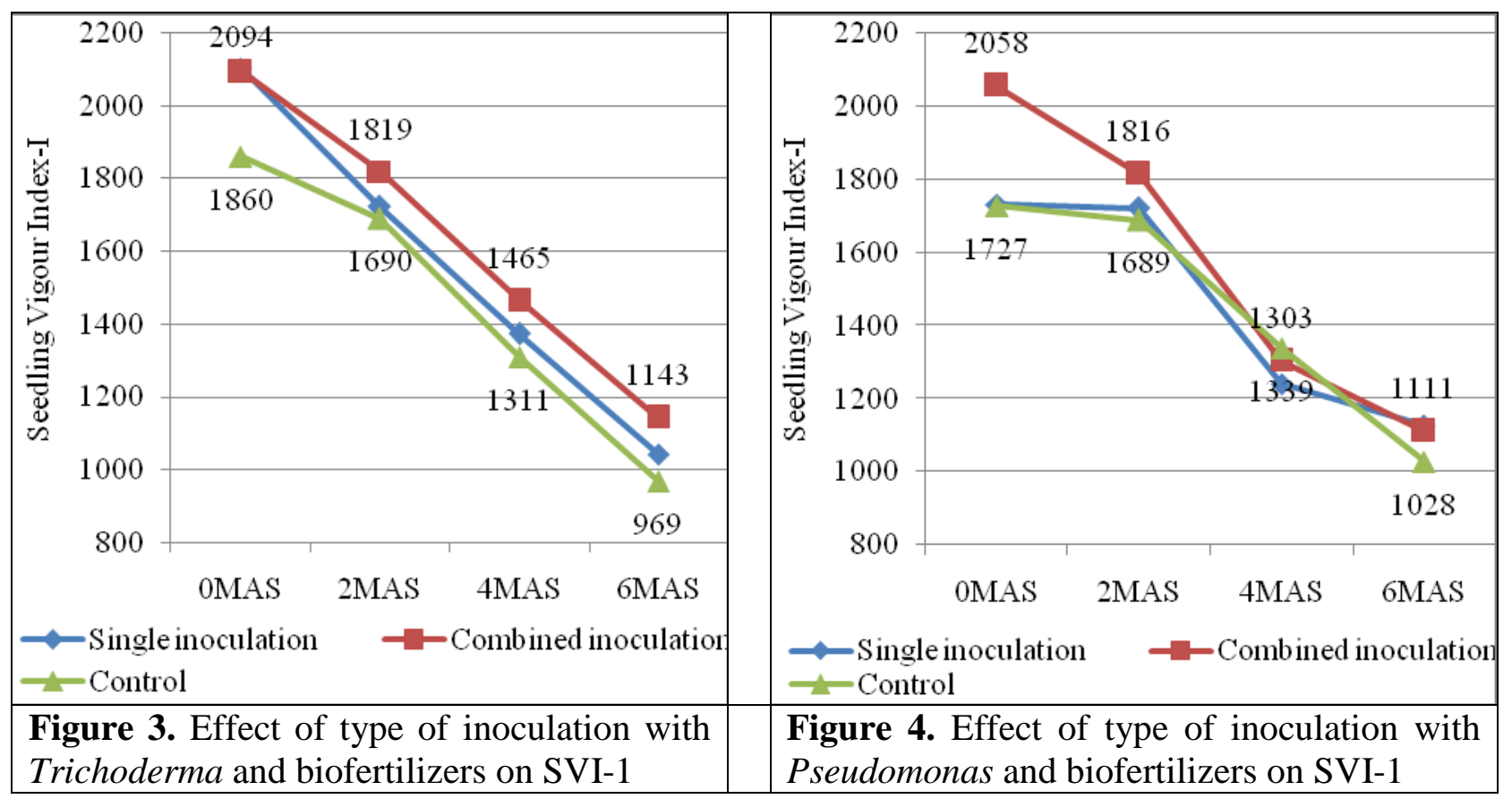

Note: MAS-Months After Storage

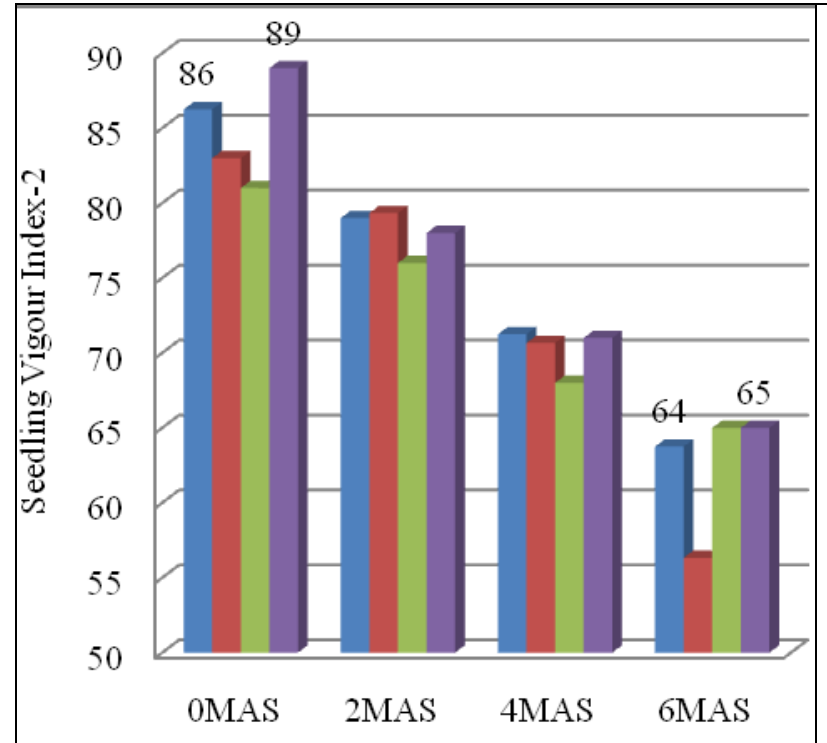

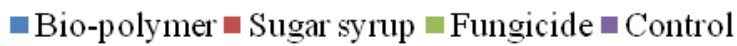

Figure 5. Effect of seed coating material and Trichoderma, Rhizobium and PSB on SVI-2

Note: MAS-Months After Storage

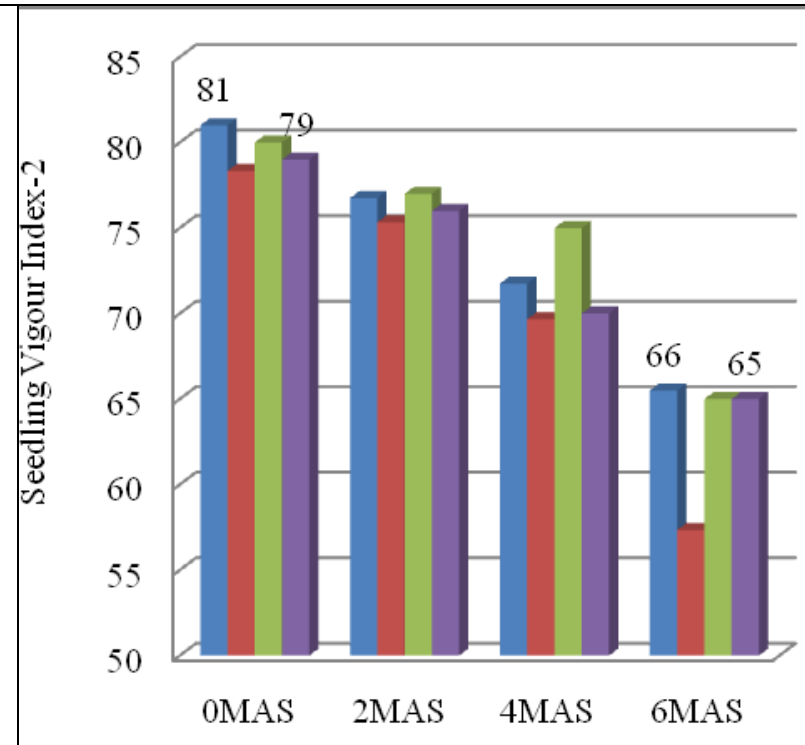

$\varpi$ Bio-polymer $\square$ Sugar syrup $₫$ Fungicide $₫$ Control Figure 6. Effect of seed coating material and Pseudomons, Rhizobium and PSB on SVI-2 


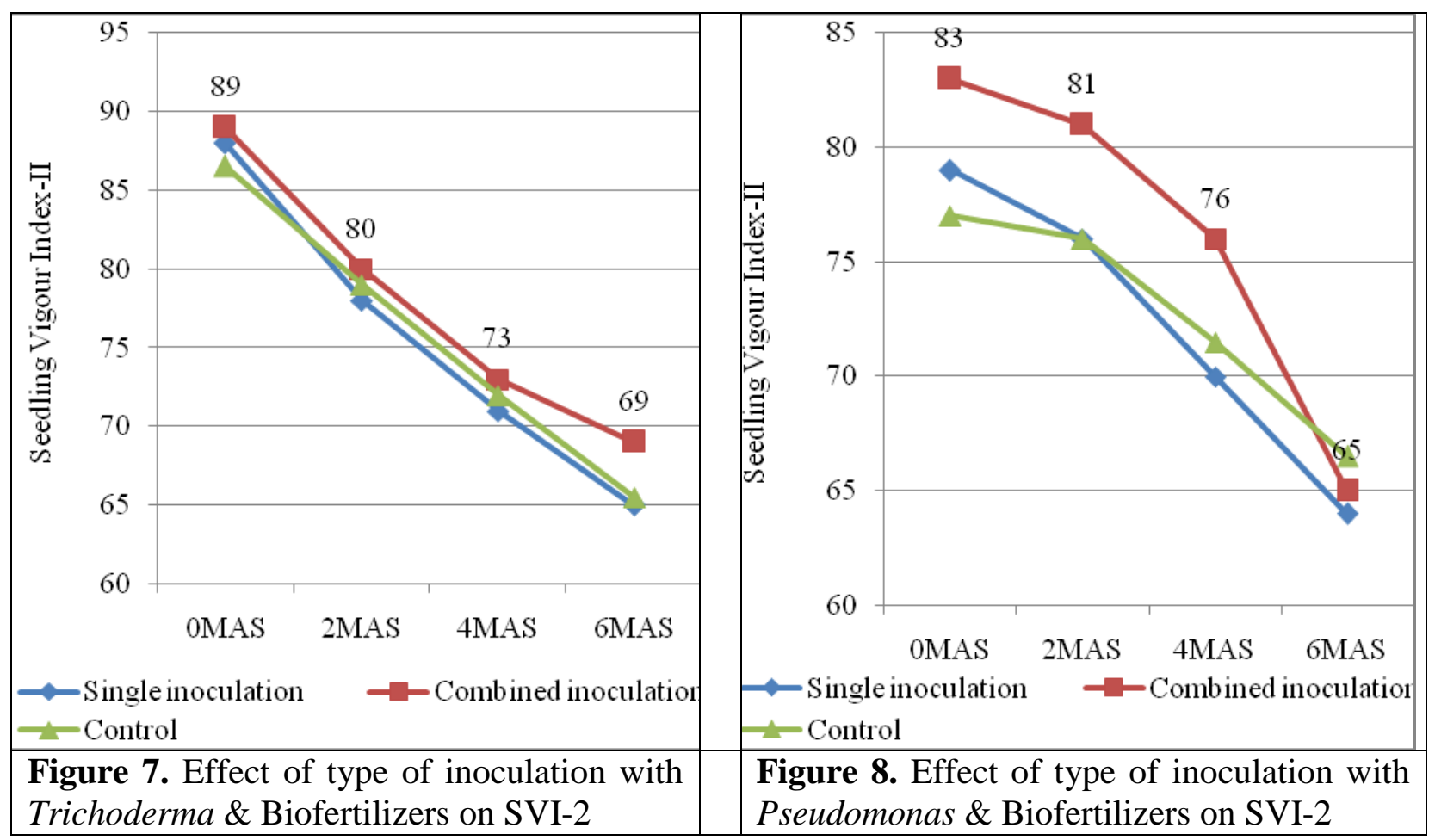

Note: MAS-Months After Storage

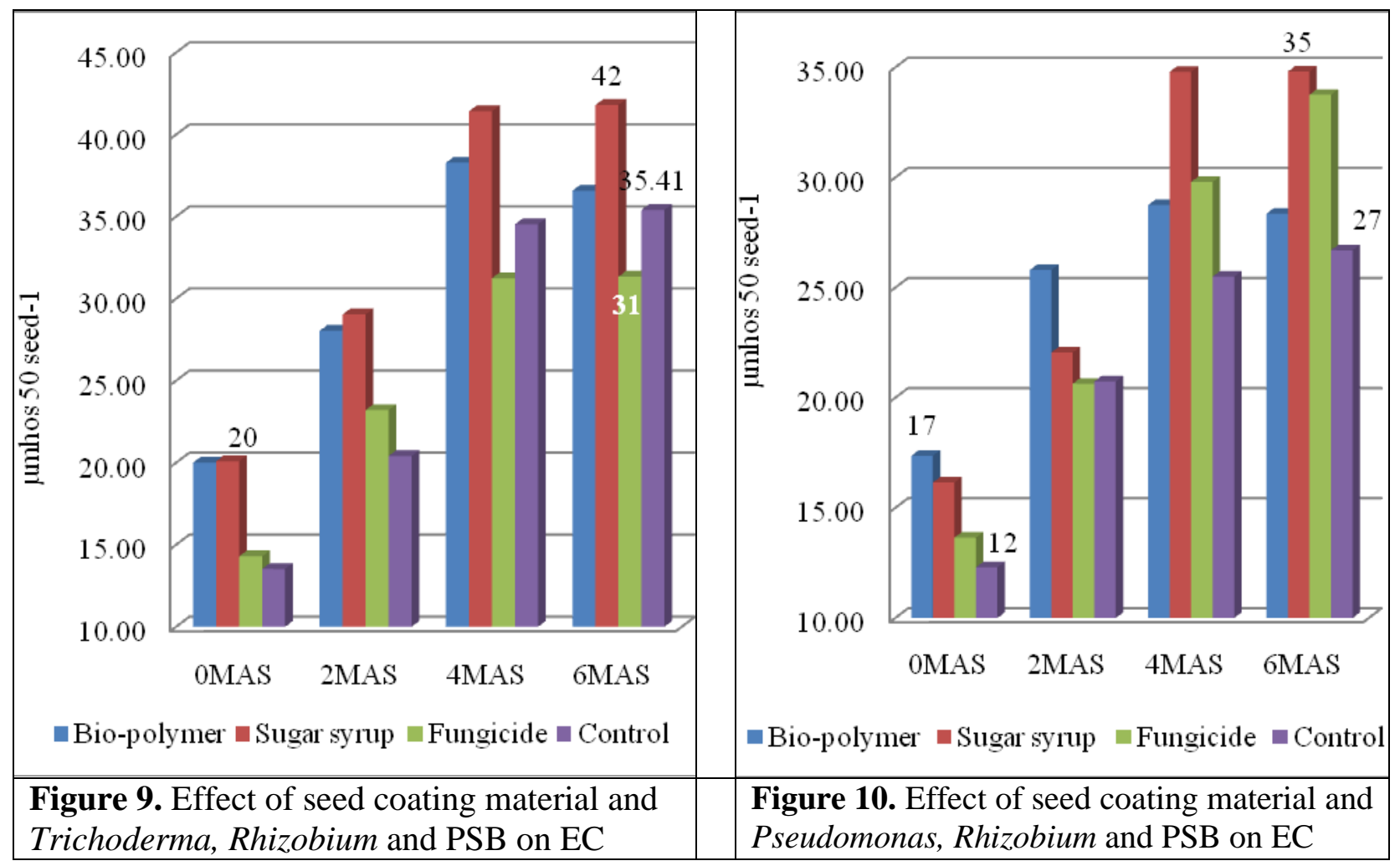

Note: MAS-Months After Storage 


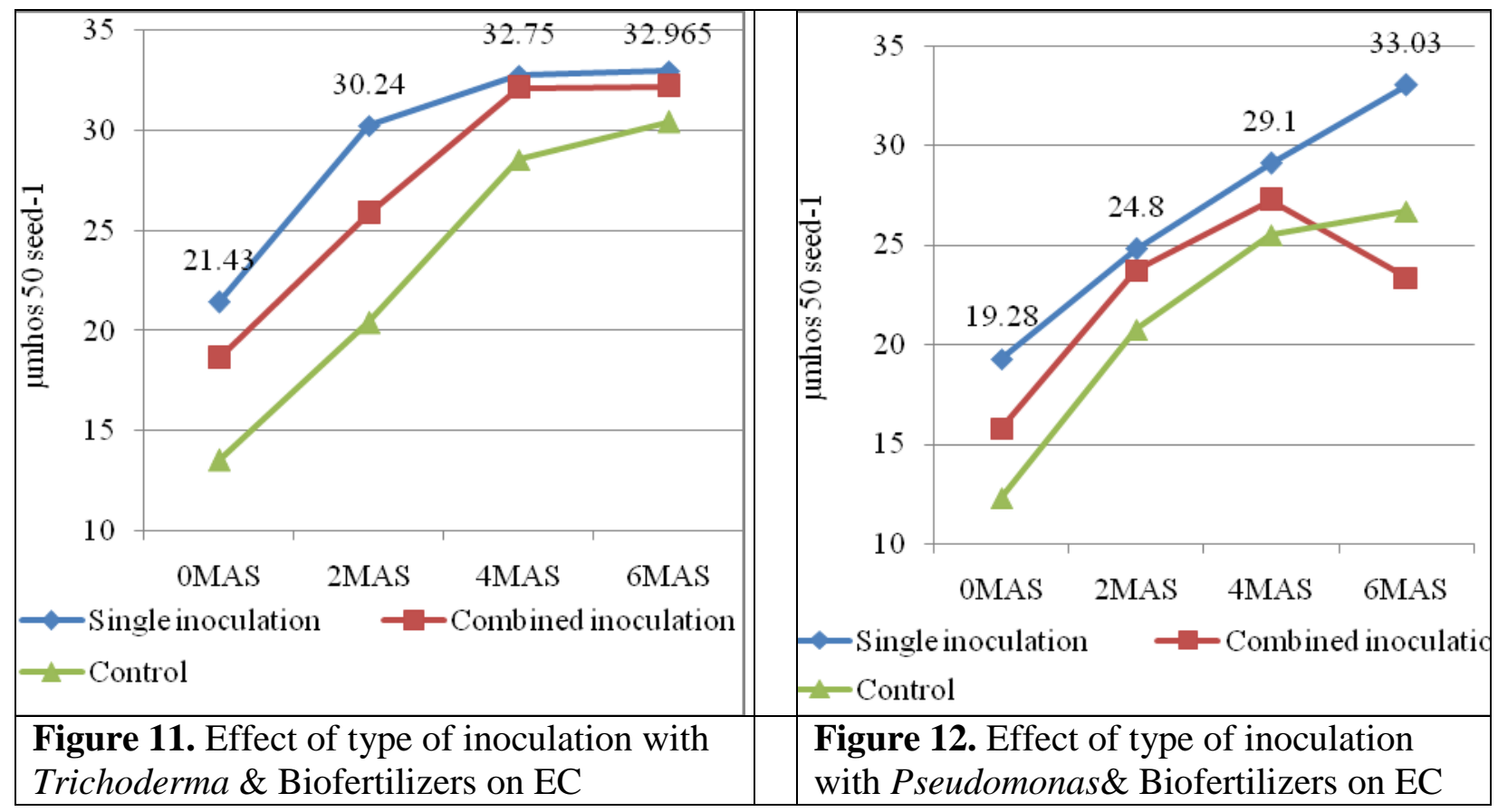

Note: MAS-Months After Storage

Effect of biological seed coating with bioprotectants and biofertilizers on pigeonpea electrical conductivity

At the end of six months of storage period, lowest electrical conductivity was recorded with polymer compared to untreated control. And highest electrical conductivity was recorded in seed, treated with Trichoderma and PSB using sugar syrup. And highest electrical conductivity was recorded in seed, treated with Pseudomonas and Rhizobium with sugar syrup. Throughout the storage period, polymer as an adjuvant reported lower leachates compared to untreated control.

Six months after storage, sugar syrup reported higher electrical conductivity. These findings are in line with Chachalis and Smith (2001) who have reported that seed coating with hydrophobic polymer Vinamul 3650 could lower the solute leakage in aged soybean seeds compared to sugar syrup. This might be due to the fact that the polymer might have acted as barrier against environmental stress factors and it might have also involved in the cell membrane repair mechanism.

\section{Acknowledgements}

The authors gratefully acknowledge the financial help rendered by the Professor Jayashankar Telangana State Agricultural University, Hyderabad and technical support rendered by the staff of the Department of Seed Science \& Technology and Department of Agriculture Microbiology and Bio-energy, College of Agriculture, Rajendranagar, PJTSAU, Rajendranagar, Hyderabad (India) and Centor India, Hyderabad for providing bio-friendly polymer.

\section{Conflict of Interest}

The authors do not have any conflict of interest in present research work.

\section{References}

Abdul Baki, A.A. and Anderson, J.D. 1973. Vigour determination in soybean seed by multiple criteria. Crop Sci., 13: 630633.

Ambika, S., Bhaskaran, M., Manonmani, V and Vanangamudi, K. 2014. Storability 
of polymer coated CORH 3 hybrid rice seeds. Oryza, 51(2): 125-130.

Chachalis, D. and Smith, M.L. 2001. Hydrophilic polymer application reduces imbibition rate and partially improve germination or emergence of soybean seedlings. Seed Sci. Technol., 29(1): 91 - 98.

Food and Agriculture Organization (FAO). 2016.

Indian Institute of Pulse Research (IIPR). 2014. www.iipr.com.

International Seed Testing Association (ISTA). 2009.

Kaushik, K.S. and Kumar, R. 2014. Effect of polymer film coating, fungicide and storage treatment on vigour and viability of maize seeds. Trends in Biosci., 7(17): 2361-2364.

Kaushik, S.K., Rai, A.K and Singh, V. 2014. Seed quality of maize with polymer film coating in Storage. Int. J. Innovative Res. Sci. Engi. Technol., 3: 1435314358.

Panse, V.G. and Sukhatme, P.V. 1985. Statistical methods for agricultural workers. $2^{\text {nd }}$ edn. pp/381, I.C.A.R., New Delhi.

Shakuntala, N.M., Vyakaranahal, B.S., Shankergoud, I., Deshpande, V.K., Pujari, B.T and Nadaf, H.L. 2010. Effect of seed polymer coating on growth and yield of sunflower hybrid
RSFH-130. Karnataka J. Agri. Sci., 23(5): 708-11.

Singh, R., Arora, N.K., Preeti, G. and Shattarohan, L. 2013. Enhancement of plant growth of Trigonella foenumgraecum by coinoculation of fluorescent Pseudomonas and Rhizobium for the sustainability of agriculture. Asian $J$. Plant Sci. Res., 3(3): 74-79.

Verma, J.P., Yadav, J and Tiwari, K.N. 2010. Application of Rhizobium spp. (BHURC01) and Plant Growth Promoting Rhizobacteria on nodulation, plant bio mass and yield of Chick pea (Cicer arietenum.L). Int. J. Agri. Res., 5(3): 148-156.

Verma, O. and Verma, R.S. 2014. Effect of seed coating material and storage containers on germination and seedling vigour of soybean (Glycine max L.). SAARC J. Agri., 12(2): 16-24.

Vinod kumar, S.B., Vyakaranahal, B.S., Dhananjaya, P., Hipparagi, Y and Asha, A.M. (2013) Effect of seed polymer coating on field performance and quality of pigeon pea (Cajanus cajan (L.). Environ. Ecol., 31(1): 43-46.

Yadav, J., Verma, J.P and Tiwari, K.N. 2010. Effect of plant growth promoting Rhizobacteria on seed germination and plant growth chickpea (Cicer arietinum L.) under in vitro conditions. Biol. Forum, 2(2): 15-18.

\section{How to cite this article:}

Jagadeesh, V., Sujatha Patta, S. Triveni, K. Keshavulu, K. Jhansi Rani and Kavali Raghavendra. 2017. Effect of Biological Seed Coating on Pigeonpea Seedling Vigour. Int.J.Curr.Microbiol.App.Sci. 6(8): 843-854. doi: https://doi.org/10.20546/ijcmas.2017.608.107 